\title{
Antigonon leptopus invasion is associated with plant community disassembly in a Caribbean island ecosystem
}

\author{
Maarten B. Eppinga (ib - Elizabeth A. Haber · Luke Sweeney • Maria J. Santos • \\ Max Rietkerk • Martin J. Wassen
}

Received: 28 April 2021 / Accepted: 5 October 2021/Published online: 15 November 2021

(C) The Author(s) 2021

\begin{abstract}
Invasions by non-native plant species are widely recognized as a major driver of biodiversity loss. Globally, (sub-)tropical islands form important components of biodiversity hotspots, while being particularly susceptible to invasions by plants in general and vines in particular. We studied the impact of the invasive vine A. leptopus on the diversity and structure of recipient plant communities on the northern Caribbean island St. Eustatius. We used a paired-plot design to study differences in species richness, evenness and community structure under $A$. leptopus-invaded and uninvaded conditions. Community structure was studied through species co-occurrence patterns. We found that in plots invaded by $A$. leptopus, species richness was $40-50 \%$ lower, and these plots also exhibited lower evenness. The magnitude of these negative impacts increased with increasing cover of A. leptopus. Invaded plots also showed higher degrees of homogeneity in species
\end{abstract}

M. B. Eppinga $(\bowtie) \cdot$ M. J. Santos

Department of Geography, University of Zurich,

Winterthurerstrasse 190, 8057 Zurich, Switzerland

e-mail: Maarten.Eppinga@geo.uzh.ch

E. A. Haber - L. Sweeney - M. Rietkerk · M. J. Wassen Copernicus Institute of Sustainable Development, Environmental Science Group, Utrecht University, Princetonlaan 8a, 3584 CB Utrecht, The Netherlands

L. Sweeney

School of Archaeology, Geography and Environmental

Science (SAGES), University of Reading, Reading, UK composition. Species co-occurrence patterns indicated that plant communities in uninvaded plots were characterized by segregation, whereas recipient plant communities in invaded plots exhibited random cooccurrence patterns. These observations suggest that invasion of A. leptopus is not only associated with reduced species richness and evenness of recipient communities in invaded sites, but also with a community disassembly process that may reduce diversity between sites. Given that A. leptopus is a successful invader of (sub-)tropical islands around the globe, these impacts on plant community structure highlight that this invasive species could be a particular conservation concern for these systems.

Keywords Biodiversity impacts · C-score analysis . Community diversity $\cdot$ Evenness $\cdot$ Exotic plant invasion $\cdot$ Species richness

\section{Introduction}

Invasions by non-native plant species represent an important ecological driver of ecosystem change, exerting profound impacts on biodiversity, ecosystem services and human well-being (Olson 2006; Pejchar and Mooney 2009; Vilà et al. 2011; Bellard et al. 2016; Shackleton et al. 2019). These impacts can result from a range of mechanisms, including the direct exclusion of native species (Reed et al. 2005; Molinari and 
D'Antonio 2014; Bradley et al. 2019; De la Riva et al. 2019), and biotic homogenization at the expense of endemic species (McKinney and Lockwood 1999; Olden et al. 2004; Sax and Gaines 2008; Santos et al. 2011; Khanna et al. 2012; Kortz and Magurran 2019; Galán-Díaz et al. 2020). The latter mechanism is of particular concern for (sub-)tropical island archipelagos. These islands are characterized by high levels of endemism due to unique evolutionary histories (Myers et al. 2000; Brown and Sax 2004; Sloan et al. 2014). Moreover, (sub-)tropical islands have experienced the highest numbers of non-native plant invasions (Essl et al. 2019). While the impacts of invasive plant species on the diversity of recipient plant communities have been well documented in general (Vilà et al. 2011; Mollot et al. 2017; Pyšek et al. 2017; Peng et al. 2019), the specific impacts of invasive plant species in (sub-)tropical island ecosystems have been studied less in comparison (Pyšek et al. 2008; Sax and Gaines 2008; Lowry et al. 2013; Jeschke et al. 2018; Peng et al. 2019).

A straightforward way to assess the impact of nonnative invasive plants on recipient communities is to compare species richness and evenness in pre- and post-invasion conditions (e.g. Heard et al. 2012). Through this approach, one can demonstrate that invasive species establish and expand at the expense of a decline in (native) species richness (Diekmann et al. 2016). However, in cases where space-for-time substitutions are used instead of longitudinal studies, it becomes more challenging to determine whether invasive species are driving or responding to variation in (native) species diversity (MacDougall and Turkington 2005; Bauer 2012; Cassini 2020). Moreover, the magnitude of invasive plant species' impacts may depend on contextual factors such as climate, habitat, land use and land cover characteristics (Gaertner et al. 2009; Vilà et al. 2011; Casado et al. 2015; MartinForés et al. 2015, 2017; Diekmann et al. 2016; Mollot et al. 2017; Pyšek et al. 2017). Specifically, previous studies have shown how recipient plant community richness in urbanized landscapes may be more negatively impacted by invasive species than recipient plant communities in more natural landscapes (González-Moreno et al. 2017; Gutiérrez-Cánovas et al. 2020; but see Martin-Forés et al. 2017).

In addition to negatively impacting the species richness of recipient plant communities, invasive species may exert more pervasive impacts as well, including the disruption of plant-pollinator networks (Traveset and Richardson 2006; Vilà et al. 2009), abiotic habitat modification (Crooks 2002; Cuddington and Hastings 2004) and community disassembly (Sanders et al. 2003; Dostál 2011; Santoro et al. 2012). The latter refers to the process of non-random species losses and declines (sensu Zavaleta et al. 2009), and may generate additional changes in the structure of recipient plant communities (Sanders et al. 2003; Mangla et al. 2011; Santoro et al. 2012). To identify structure at the plant community level, species cooccurrence analyses can show whether species tend to segregate or aggregate (Stone and Roberts 1990; Gotelli 2000; Ulrich and Gotelli 2013). Species aggregation means that species tend to co-occur more often than expected from random co-occurrence, and may indicate the prevalence of facilitative interactions (Santoro et al. 2012; de Miguel et al. 2016). In contrast, species segregation means that species tend to co-occur less frequently than expected from random co-occurrence, and may indicate the prevalence of competitive interactions (Santoro et al. 2012; de Miguel et al. 2016; but see Ulrich et al. 2017). In addition to identifying patterns of species aggregation and segregation, co-occurrence analyses can also be used to infer the sign and magnitude of associations between particular pairs of species (Blois et al. 2013; Veech 2014; Verwijmeren et al. 2014; Lai et al. 2015; $\mathrm{Li}$ and Waller 2016; Waller et al. 2016). Within the context of plant invasion, a globally coordinated survey suggested that non-native plant species tend to aggregate in the non-native habitat, especially in patches with relatively high biomass and relatively small numbers of species (Stotz et al. 2020).

The Caribbean region includes multiple (sub)tropical island archipelagos and is considered a global biodiversity hotspot, containing a large proportion of endemic species even when compared to other hotspots (Myers et al. 2000; Sloan et al. 2014). On Caribbean islands, lowland ecosystems are particularly susceptible to plant invasions (Kueffer et al. 2010), with climatic conditions favorable to the growth of lianas and vines (Schnitzer 2005; Schnitzer and Bongers 2011). These functional vegetation groups form a particular invasion concern, as they not only smother native vegetation, but also modify edaphic conditions (e.g. carbon and nitrogen dynamics, Bray et al. 2017; Ward et al. 2020) and microclimatic conditions (e.g. humidity, Gordon 1998; 
Horvitz et al. 1998). These processes may drive disproportionate ecosystem impacts as compared to invasive plant species of other growth forms that do not actively modify the environmental conditions for the recipient plant community (Crooks 2002; Cuddington and Hastings 2004; Harris et al. 2007; Kaproth et al. 2013; Gordon et al. 2017).

The aim of this study was to document the impact of invasion by the vine Antigonon leptopus on the Caribbean island of St. Eustatius. Specifically, we were interested in the impacts of A. leptopus on the diversity and structure of St. Eustatius' recipient plant communities. We addressed whether invasion by $A$. leptopus: (1) impacts the recipient plant communities' richness and evenness, and whether these impacts are mediated by land cover type; (2) leads to homogenization of recipient plant communities; (3) modifies species co-occurrence patterns; (4) differentially impacts native and non-native plant species. Based on general trends observed in the non-native plant invasion literature, we deducted the following hypotheses for our case study: (1) A. leptopus negatively impacts recipient plant community richness and evenness (Vilà et al. 2011; Mollot et al. 2017; Pyšek et al. 2017), and these effects are strongest in urban areas (González-Moreno et al. 2017; Gutiérrez-Cánovas et al. 2020). It is also hypothesized that these impacts increase linearly with increasing abundance of A. leptopus (Bradley et al. 2019); (2) Plant community composition in urban and semi-natural habitats is more homogeneous when these habitats have been invaded by A. leptopus (Huebner et al. 2012; Dar and Reshi 2015); (3) The sub-tropical lowland ecosystems of St. Eustatius are relatively benign habitats, and under such low stress conditions plant interactions may be dominated by competition (Maestre et al. 2009), which would be reflected in species segregation (Santoro et al. 2012; de Miguel et al. 2016). Invasion by A. leptopus, however, may disrupt these interactions and lead to a shift toward random co-occurrence patterns (Sanders et al. 2003; Santoro et al. 2012); and lastly 4) Non-native species co-occur more frequently with A. leptopus than native species (Stotz et al. 2020).

\section{Material and methods}

Study area

The research was conducted on St. Eustatius $\left(17^{\circ} 28^{\prime}\right.$ $\mathrm{N}, 62^{\circ} 58^{\prime} \mathrm{W}$ ), a northern Caribbean island that is part of the Cenozoic lesser Antilles volcanic island arc (Macdonald et al. 2000; Eppinga and Pucko 2018). The island consists of two volcanic complexes, the Quill in the southeastern part and the Northern Mountains in the northwestern part of the island, which were connected by lava flows resulting from eruptions of the Quill in the early Holocene (Rojer 1997; Roobol and Smith 2004). St. Eustatius' climate is tropical, with a mean annual temperature of $25.7{ }^{\circ} \mathrm{C}$ and mean annual precipitation of $1073 \mathrm{~mm}$ (Rojer 1997), but climate varies with elevation (Boldingh 1909; De Freitas et al. 2012). The mountain slopes are covered by various types of forest (described in: Stoffers 1956, Rojer 1997, De Freitas et al. 2012, Van Andel et al. 2016; Eppinga and Pucko 2018). The flatter, middle part of the island connecting the volcanic complexes is called the Kultuurvlakte. This area is dominated by grasslands, and has experienced intense anthropogenic disturbance (e.g. agriculture, livestock husbandry) for hundreds of years, with a higher proportion of non-native species occurring within its lowland ecosystems (Fig. 1; De Freitas et al. 2012; Axelrod 2017; Haber et al. 2021). Antigonon leptopus is the most successful and aggressive invasive species on the island (Ernst and Ketner 2007; Van der Burg et al. 2012; Haber et al. 2021), and will be described in further detail in the following section.

Study species

Antigonon leptopus (Hook. \& Arn., common name(s): Coral vine and Coralita) is a perennial vine that is originally from Mexico, where it can be found in a wide range of habitats (Burke and DiTomasso 2011; CABI 2017; Vandebroek et al. 2018). The species' prolific production of flowers constitutes a nectar source for honey production, and makes it a popular ornamental plant (e.g. Burke and DiTomasso 2011; Zhang et al. 2017; Vandebroek et al. 2018), which has contributed to its spread throughout the global tropics (Burke and DiTomasso 2011), including the Caribbean (Mitchell et al. 2019). Antigonon leptopus tends to grow a network of rhizomes, from which shoots can 


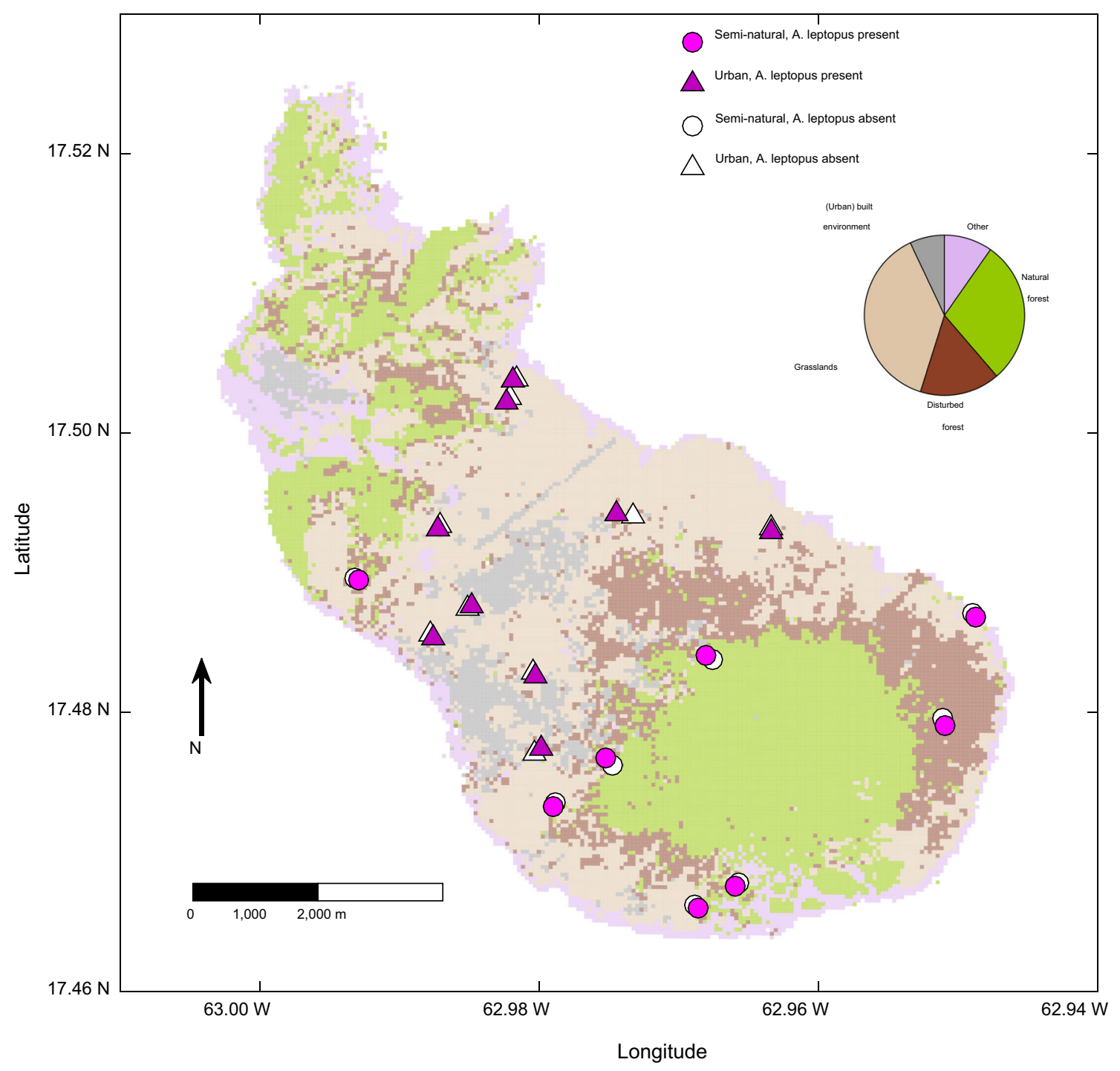

Fig. 1 Map of St. Eustatius (northern Caribbean), showing the different types of land use on the island, and the locations of the plots that were surveyed in the present study. Land use categories were identified by Helmer et al. (2008), and subsequently further aggregated into five different categories (following Haber et al. 2021). Different symbols indicate the different type of survey plots considered in the study. Magenta-

grow up to $25 \mathrm{~cm}$ per month (Ernst and Ketner 2007). The species can also spread by seed (Burke and DiTomasso 2011). Antigonon leptopus can grow in challenging environments such as those with low light availability and poor soils (Vandebroek et al. 2018). The vine climbs and smothers taller vascular plants (Surendra et al. 2013), but it can also 'creep' by expanding laterally over bare areas or grasslands colored symbols indicate sampling locations where the focal invasive species, A. leptopus was the dominant species (i.e. covering at least $50 \%$ of the plot area). Using a paired-plot design, each of these plots was compared to a nearby plot without A. leptopus (white symbols). Ecological impacts of $A$. leptopus were compared between areas dominated by urban (triangles) and semi-natural (circles) land cover types

through propagation of rhizomes, stolons or tubers (Burke and DiTomasso 2011; Vandebroek et al. 2018). The size and depth of the tubers and rhizomes of the species, as well as its hardiness and its various modes of spread make A. leptopus a challenging species to eradicate (Ernst and Ketner 2007; Eppinga et al. 2021). The invasion of A. leptopus on the Caribbean island St. Eustatius is among the most severe 
infestations of this species in the world (Ernst and Ketner 2007; Burke and DiTomasso 2011; Haber et al. 2021). Hence, St. Eustatius provides a valuable case study of the impact of A. leptopus' invasion in plant community diversity and structure. Despite the many observations of A. leptopus invasions around the globe, these impacts have not yet been systematically quantified (Heger and Van Andel 2019).

\section{Field data collection}

Field data were collected in November and December of 2018. We selected 17 locations for paired plot sampling on St. Eustatius (Fig. 1). These locations covered the range on St. Eustatius in which A. leptopus is present in patches greater than $100 \mathrm{~m}^{2}$ (Haber et al. 2021), the full plot size used in this study (see below). The median geographical (Euclidean) distance to the nearest neighboring sampling location was $526 \mathrm{~m}$ (range: 155-1131 m, Fig. 1). As we were interested in inferring relationships between A. leptopus invasion, land cover type and plant community similarity, we verified that community similarities between plots were not confounded by the geographical (Euclidean) distances between plots (Fig. 1). Indeed, we found that community similarity did not significantly correlate with the geographical (Euclidean) distance between plots (Mantel test: Spearman's $\rho=-0.03, p=0.61$ ).

The sampling locations were stratified according to land cover type, with 9 plots occurring in urban grassland areas and 8 plots in semi-natural forest areas. These land cover classifications were based upon the land cover distribution map of St. Eustatius by Helmer et al. (2008), further aggregated into an urban and a semi-natural land cover type (Haber et al. 2021), which were also used in this study. At each location, we selected a plot invaded ( $\geq 50 \%$ cover) by $A$. leptopus, and a plot in close proximity that was not invaded ( $0-1 \%$ cover) by A. leptopus. The median distance between paired invaded and uninvaded plots was $36 \mathrm{~m}$ (range: $30-127 \mathrm{~m}$, Fig. 1). This paired-plot design enabled assessment of the impact of A. leptopus invasion on recipient plant community diversity and structure (e.g. Vilà et al. 2006; Castro-Diéz et al. 2016). Plot size was $10 \mathrm{~m}$ by $10 \mathrm{~m}$. Within these plots, we recorded which species were present. Photographs were taken at each plot and voucher specimens were collected and deposited at the University of Puerto Rico herbarium (code: MAPR). The status of each species (i.e. non-native or native) was obtained from the Dutch Caribbean Species Register (Naturalis Biodiversity Center 2017) and a systematic vademecum about the vascular plants of St. Eustatius (Axelrod 2017). For a subset of locations (7 urban and 7 seminatural plots), we also estimated the abundance (in $\%$ cover) of the species present within a $2 \mathrm{~m}$ by $2 \mathrm{~m}$ subplot that was located near the plot center. For species with a total cover of $<10 \%$ a cover estimate was made based on the number of individuals present (rounded to the nearest \%), and the average size of these individuals. For species with a total cover of $>10 \%$, cover was estimated visually and rounded to the nearest $5 \%$ (i.e. $10 \%, 15 \%, \ldots, 100 \%$ ). We used cover as a measure of abundance, as it allowed for non-destructive sampling of sites, and generally community composition as measured through cover corresponds well to estimates requiring destructive sampling (i.e. aboveground biomass, Chiarucci et al. 1999; Chen and Shiyomi 2019). The plot size of $2 \mathrm{~m}$ by $2 \mathrm{~m}$ is often used in invasive plant species' impact surveys, as it provides a comprise between sampling at the scale of plant-plant interactions, while minimizing spatial variation in other environmental variables (e.g. Vilà et al. 2006; Gallego-Fernández et al. 2019).

Data analyses

Impact on species richness and evenness, and mediation by land cover type

We tested our first hypothesis using data collected at both the full plot $(10 \mathrm{~m}$ by $10 \mathrm{~m})$ and subplot $(2 \mathrm{~m}$ by $2 \mathrm{~m})$ scale. We tested for differences in species richness using generalized linear mixed-effects models, with land cover type and degree of A. leptopus invasion (i.e. uninvaded or invaded) as fixed effects, and location (i.e. a pair of an invaded and an uninvaded plot) as a random effect. We used a Poisson distribution for species counts and a logarithmic link function.

Species evenness was calculated differently for the full plots and the subplots. For the full plots, the abundance of each species was calculated as the proportion of plots in which the species was present. This means that only one evenness value could be calculated for the invaded plots, and one value for the uninvaded plots, for which no statistical difference test 
was employed. In contrast, for each subplot, we calculated the Shannon-Wiener index:

$H_{j}=-\sum_{i=1}^{n} \frac{N_{i, j}}{N_{T o t, j}} \ln \frac{N_{i, j}}{N_{T o t, j}}$

In which $H$ is the Shannon-Wiener index for subplot $j, N_{i, j}$ is the $\%$ cover of species $i$ in plot $j$, and $N_{\text {Tot }, j}$ is the total cover of subplot $j$ (which can be higher or lower than $100 \%$ ). We tested for differences in evenness using a linear mixed-effects model, with land cover type and degree of A. leptopus invasion as fixed effects, and location (i.e. a pair of an invaded and an uninvaded plot) as a random effect. Differences in evenness between invaded and uninvaded plots were calculated for both the urban and semi-natural land cover types. These analyses, as well as all other analyses performed in this study, were carried out in MATLAB (v. 9.6, Mathworks, 2019), making use of functions implemented in the Mapping and the Statistics and Machine Learning toolboxes.

Subsequently, we analyzed the impacts of $A$. leptopus invasion on the structure of recipient plant communities. We used the abundance of A. leptopus in $2 \mathrm{~m}$ by $2 \mathrm{~m}$ subplots as an indicator of invasion stage, and assessed whether invasion stage correlated with species richness in both the subplots and full plots. Following Bradley et al. (2019), we tested whether the recipient plant community richness was better described by a linear per capita effect of A. leptopus or a non-linear per capita effect. A non-linear per capita effect would suggest density-dependent impacts, which may depend on the invasive species exceeding a critical abundance threshold, for example (Thiele et al. 2010; Bradley et al. 2019; Michaels et al. 2020). Specifically, we fitted both linear and a nonlinear regression models and tested significance of (non-)linear model terms using the confidence intervals of the regression coefficients.

\section{Community similarity between invaded and uninvaded plots}

To test our second hypothesis, we assessed similarities between plant communities using the presence-absence data of the species observed in both the full plots and the subplots. The high dimensionality of these data was reduced through non-metric Multi-Dimensional Scaling (nMDS). The nMDS procedure extracts a limited number of axes that explain variation between observations without making distributional assumptions, and is widely used in analyses of plant community similarity (e.g. Hedman et al. 2000; McCune and Grace 2002; Pucko et al. 2011). We compared the community similarity between invaded and uninvaded plots, and examined how this comparison depended on land cover type. We limited the analyses to two nMDS axes, because this provided reliable fits with stress values $<0.2$ (Clarke 1993; Pucko et al. 2011; Barfknecht et al. 2020). Stress values are used to assess the goodness-of-fit of the ordination, quantifying the degree of mismatch between the (rank-ordered) multi-variate distance between plots and their relative distance in the twodimensional ordination space (Pucko et al. 2011). For each group of plots, we calculated the convex hull, i.e. the polygon formed by all observations of the group in community composition space, as a measure describing the variation of community composition within that group and its overlap with other plot groups (Villéger et al. 2008).

\section{Assessing change in the structure of recipient plant communities}

To test our third hypothesis, we examined whether $A$. leptopus invasion was associated with the disassembly of species in recipient plant communities by analyzing how species co-occurrence patterns differed between invaded and uninvaded plots (Sanders et al. 2003; Santoro et al. 2012; de Miguel et al. 2016). For this analysis, we used observations at the full plot scale. Specifically, we quantified for each species pair the degree of co-occurrence through the standardized Cscore (Stone and Roberts 1990; Gotelli and Ulrich 2010):

$C_{p q}=\frac{\left(k_{p}-K\right)\left(k_{q}-K\right)}{k_{p} k_{q}}$

In which $C_{p q}$ indicates the standardized C-score for the pair formed by species $p$ and species $q$, and $K$ is the number of plots in which these two species co-occur. The parameters $k_{p}$ and $k_{q}$ indicate the number of occurrences of species $p$ and species $q$, respectively. The standardized C-score varies between 0 and 1 , where 0 indicates that one species' occurrence completely overlaps with the other species' occurrence $\left(k_{p}\right.$ 
and/or $k_{q}$ equals $K$ ) and 1 indicates no overlap in occurrence ( $K$ equals zero). The $\mathrm{C}$-score of a community is then given by the average $\mathrm{C}$-score of the $n(n-1) / 2$ species pairs in the $n$ species community. Subsequently, a randomization test can be used to derive the probability of observing a particular Cscore under the null hypothesis of random community assembly (Gotelli 2000; Gotelli and Ulrich 2010). Specifically, after calculating C-scores for multiple randomizations of the co-occurrence matrix, it is possible to calculate a Standardized Effect Size (SES, e.g. Gotelli and Rohde 2002; Sanders et al. 2003; Ulrich and Gotelli 2010):

$S E S_{p q}=\frac{C_{p q, o b s}-\bar{C}_{p q, s i m}}{\sigma_{p q, s i m}}$

In which $S E S_{p q}$ is the standardized effect size for the standardized $\mathrm{C}$-score of the pair formed by species $p$ and species $q, C_{p q, o b s}$ is the standardized C-score as described above, $\bar{C}_{p q, s i m}$ is the average corresponding $\mathrm{C}$-score of the replicate (randomized) simulations, and $\sigma_{p q, s i m}$ is the standard deviation of these replicate C-scores. Principles of a single sample t-test can then be used to test the null hypothesis that the SES does not differ from 0 (e.g. Gotelli and Rohde 2002; Sanders et al. 2003). Specifically, SESs larger than 2 indicate significant segregation of plant species, and SESs smaller than -2 indicate significant aggregation of plant species. Values in between -2 and 2 then indicate a species co-occurrence pattern that does not differ from randomly assembled communities (Sanders et al. 2003; Ulrich and Gotelli 2010). For this analysis, we selected the subset of species (besides $A$. leptopus) that occurred at least 5 times in the dataset $\left(\mathrm{n}=46\right.$ species, $\mathrm{n}_{\text {native }}=37, \mathrm{n}_{\text {non-native }}=6, \mathrm{n}_{\text {undeter- }}$ mined $=3$ ). Although the dominance of A. leptopus was used to distinguish invaded plots from uninvaded plots, the species itself was not used in the C-score analysis quantifying community structure in these plots (following Sanders et al. 2003).

The species co-occurrence matrix was randomized through sequentially swapping the elements of twoby-two submatrices of the form $\left[\begin{array}{ll}0 & 1 \\ 1 & 0\end{array}\right]$, yielding a matrix of the form $\left[\begin{array}{ll}1 & 0 \\ 0 & 1\end{array}\right]$, or vice versa (Gotelli and Entsminger 2001; Gotelli and Rohde 2002; Ulrich 2004; Gotelli and Ulrich 2010). The row and column indices of the first submatrix element and either the row or the column index of the second and third submatrix elements were randomly selected. Through this procedure, the species co-occurrence matrix is randomized, while keeping constant the number of species in each plot, and the total number of occurrences of each species in the dataset. First, 30,000 submatrices were selected and its elements swapped (Lehsten and Harmand 2006), after which each randomized matrix used in the analysis was created by a fixed number of additional swaps (following Gotelli and Ulrich 2010). In this study, we used 3,000 additional swaps for each randomized matrix, generating 2,000 randomized co-occurrence matrices in total for each of the analyses described above.

\section{Native and non-native species responses to A. leptopus invasion}

To test our fourth hypothesis, we used the species presence data from all full plots (including the occurrence data of A. leptopus), and calculated C-scores and SESs as described above. Subsequently, we compared the SESs of A. leptopus - native species pairs and A. leptopus-non-native species pairs. Because the SESs of native and non-native species pairs and A. leptopus were sufficiently normally distributed (verified with Jarque-Bera tests: native species: $J B=1.28, \mathrm{p}=0.37$; non-native species: $J B=0.70, \mathrm{p}=0.33)$, and variances in SES were similar for both groups (verified with a Bartlett test: $X_{1}{ }^{2}=0.009, p=0.93$ ), we compared the difference between the native and non-native species groups using a two-sample t-test. Similar to the communitylevel C-score analysis, we selected the subset of species that occurred at least 5 times in the full plots for the pairwise analysis. In this analysis, negative SESs reflect a tendency to co-occur with A. leptopus, while positive SESs reflect a tendency to occur separately from A. leptopus.

\section{Results}

Impact on species richness and evenness

In the field survey, 181 different plant species were encountered, of which 106 species were native species, and 27 species were (likely) non-native 
species. Of the remaining species observations, many comprised observations of small seedlings; 18 of these species were identified at the genus level, nine at the sub-family level, and 13 at the family level. For the remaining eight species, only a more general description could be established. For these species, the native/ non-native status remained undetermined. Species richness was $39 \%$ lower in plots invaded by $A$. leptopus (Fig. 2a; generalized linear mixed-effects model: $\quad \mathrm{N}_{\text {Uninvaded }}=25.9$ species, $\quad \mathrm{N}_{\text {Invaded }}=15.8$ species, $\mathrm{t}_{30}=-4.69, \mathrm{p}=5.510^{-5}$ ). The impact of $A$. leptopus on species richness was similar in areas with semi-natural and urban land cover (Fig. 2a; urban =
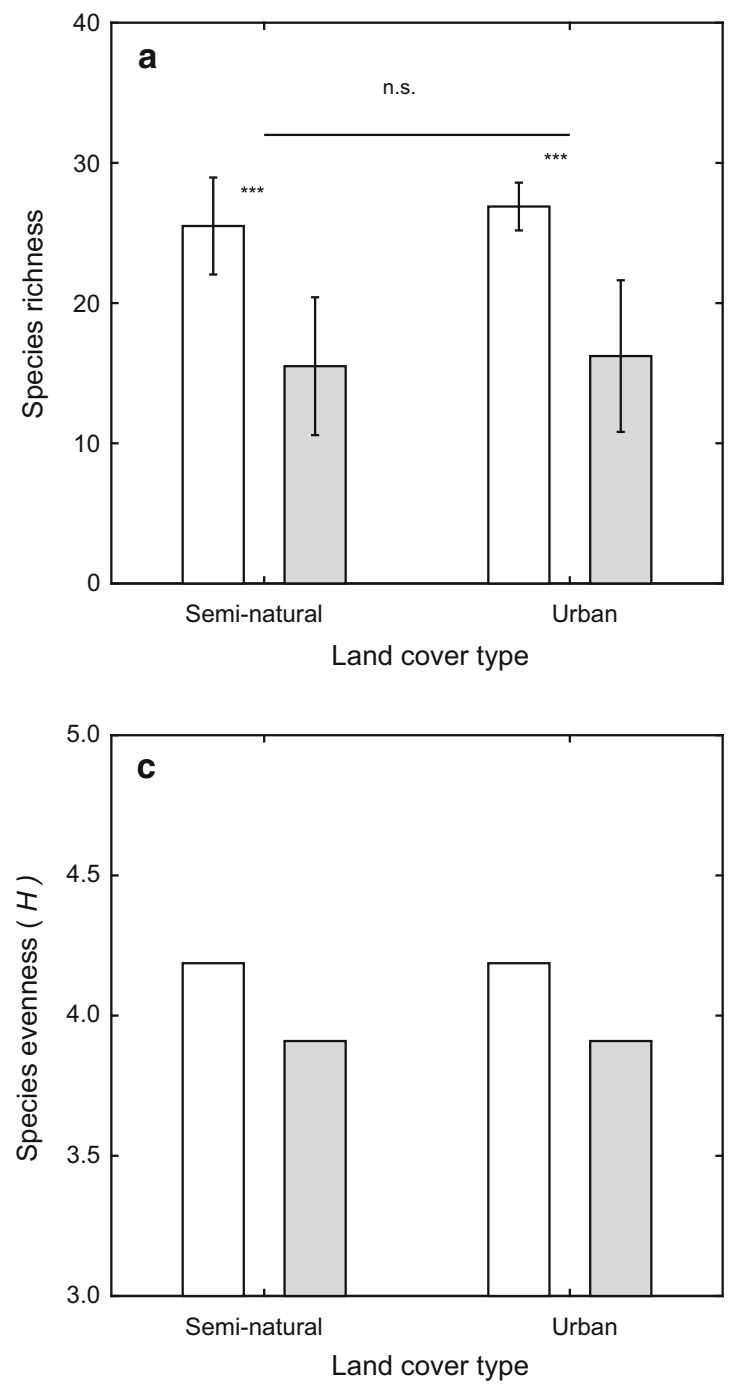

$39 \%$ lower, semi-natural $=39 \%$ lower, $\mathrm{t}_{30}=0.57$, $\mathrm{p}=0.57$ ). A similar trend was found for the smaller subplots, where species richness was $51 \%$ lower in plots invaded by A. leptopus (Fig. 2b; generalized linear mixed-effects model: $\mathrm{N}_{\text {Uninvaded }}=10.3$ species, $\mathrm{N}_{\text {Invaded }}=5.1$ species, $\mathrm{t}_{24}=-4.69, \mathrm{p}=9.110^{-5}$ ). This impact of A. leptopus on species richness in subplots was higher in areas with urban land cover than in areas with semi-natural land cover (Fig. 2b; generalized linear mixed-effects model: urban $=66 \%$ lower, $\quad$ semi-natural $=34 \%$ lower,$\quad t_{24}=2.22$, $\mathrm{p}=0.036$ ). In line with this observation, plots invaded by $A$. leptopus had lower species evenness than
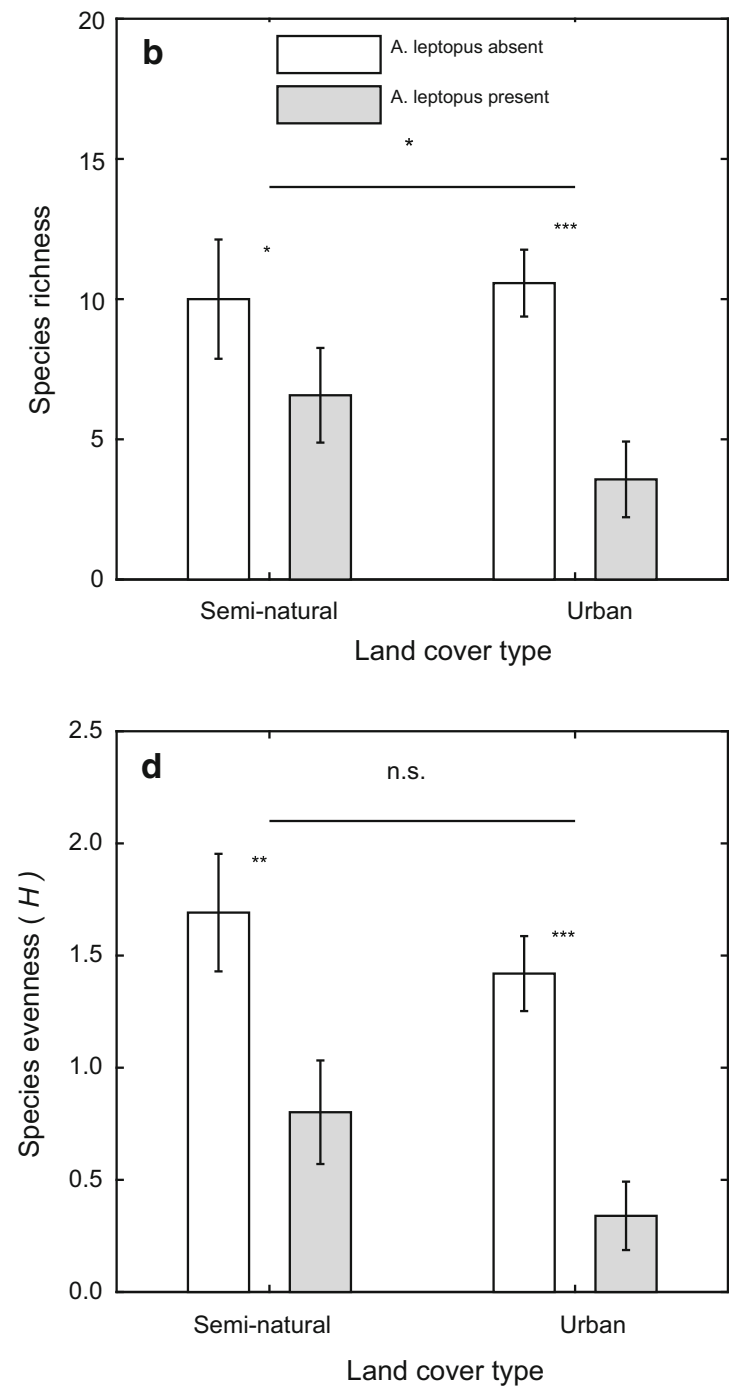

Fig. 2 The impact of invasion by A. leptopus on species richness and evenness in $10 \mathrm{~m}$ by $10 \mathrm{~m}$ plots (left) and in $2 \mathrm{~m}$ by $2 \mathrm{~m}$ subplots (right). Asterisks indicate significant differences: ***: $p<0.001 ; * *: p<0.01 ; *: p<0.05$; n.s.: not significant 
uninvaded plots (Fig. 2c, Fig. 2d; linear mixed-effects model for subplots: $\mathrm{H}_{\text {Uninvaded }}=1.56, \mathrm{H}_{\text {Invaded- }}$ $\left.=0.57, \mathrm{t}_{24}=-3.95, \mathrm{p}=0.0006\right)$. Species evenness was similar in subplots with semi-natural and urban landcover (Fig. 2d; linear mixed-effects model $\mathrm{t}_{24}=-1.00, \mathrm{p}=0.33$ ), and also the impact of $A$. leptopus invasion on species evenness was similar in subplots of both land cover types (Fig. 2d; linear mixed-effects model for subplots: Land cover type * Invasion interaction effect: $t_{24}=-0.60, p=0.56$ ).
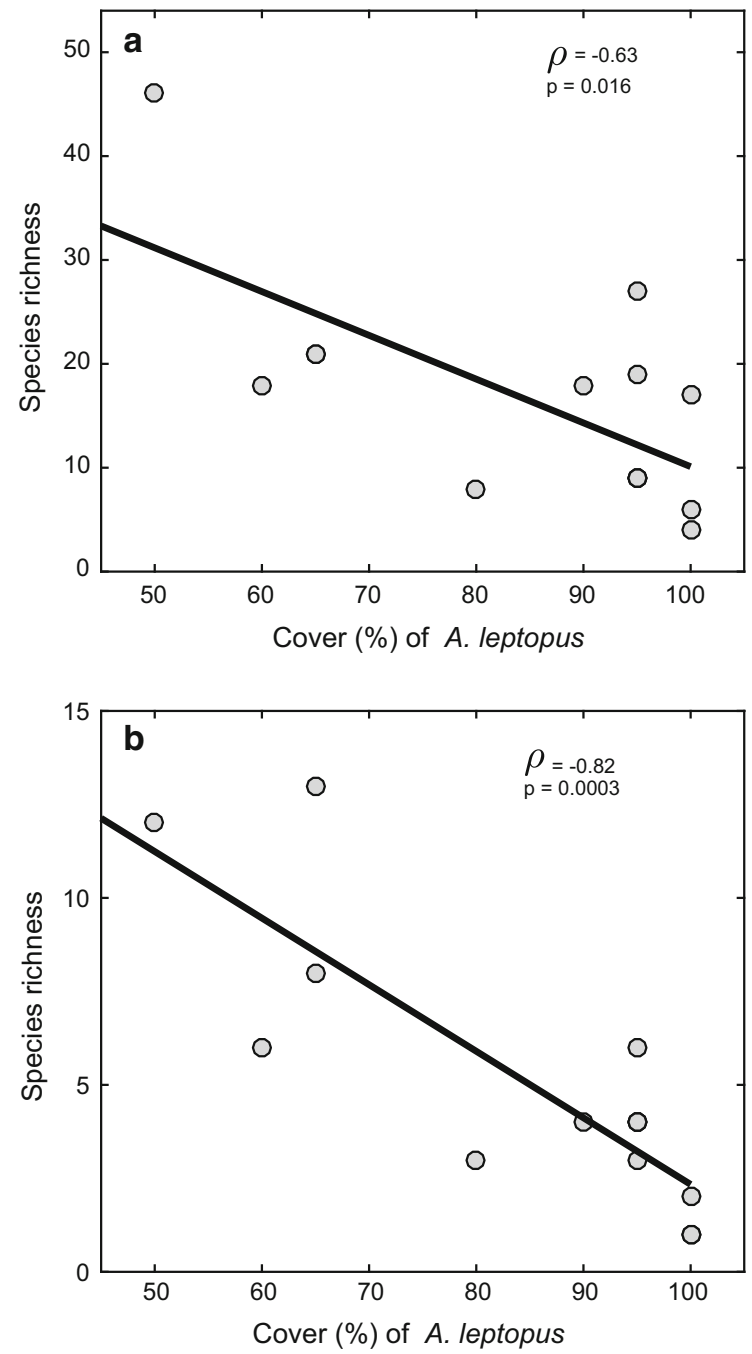

Fig. 3 Species richness decline with increasing abundance of $A$. leptopus (in \% cover) in $10 \mathrm{~m}$ by $10 \mathrm{~m}$ plots (top) and in $2 \mathrm{~m}$ by $2 \mathrm{~m}$ subplots (bottom). Results of Spearman rank correlation tests are shown in the upper right corner of each plot. Trend lines indicate linear least squares fits
Using the cover of A. leptopus in the subplot as an indicator for invasion stage, we found that species richness of the full plots (Fig. 3a) and subplots (Fig. 3b) declined with increasing dominance of $A$. leptopus (Spearman rank correlations: full plots: $\rho_{12}=-0.63, \quad \mathrm{p}=0.016 ;$ subplots: $\rho_{12}=-0.82$, $\mathrm{p}=0.0003)$. The trends in the data suggested that the impacts on species richness increased linearly with A. leptopus cover, as non-linear effects were not significant for either the full plot or subplot species richness data (least square model fitting: full plots: partial $\mathrm{R}^{2}=0.12, \quad \mathrm{p}=0.10 ; \quad$ subplots: partial $\left.\mathrm{R}^{2}<0.01, \mathrm{p}=0.98\right)$.

Community similarity between invaded and uninvaded plots

Variation in species composition between invaded plots was much smaller than the variation between uninvaded plots (Fig. 4a). As a result, invaded plots covered a much smaller proportion of the community composition space spanned by the two nMDS axes (Fig. 4a). For the $10 \mathrm{~m}$ by $10 \mathrm{~m}$ semi-natural plots, the area of the convex hull spanned by invaded plots was only $8 \%$ of the area spanned by uninvaded plots (Fig. 4a). For the $10 \mathrm{~m}$ by $10 \mathrm{~m}$ urban plots, the area of the convex hull spanned by invaded plots equaled $19 \%$ of the area spanned by uninvaded plots (Fig. 4a). The same pattern was observed for the $2 \mathrm{~m}$ by $2 \mathrm{~m}$ subplots, in that invaded subplots only spanned a small proportion of the community composition space as compared to the uninvaded subplots (Fig. 4b). In contrast to the full plots, the largest relative difference between invaded and uninvaded plots occurred in the urban plots. More specifically, the area of the convex hull spanned by invaded urban subplots was only $2 \%$ of the area spanned by uninvaded urban subplots (Fig. 4b). The area of the convex hull spanned by invaded semi-natural subplots was $16 \%$ of the area spanned by uninvaded semi-natural plots (Fig. 4b). Rather than occupying a different part of the community composition space, the convex hulls of invaded urban plots and subplots was fully captured within the convex hull of uninvaded semi-natural plots and subplots (Fig. 4), with the exception of one invaded urban plot and one invaded semi-natural plot, which contained relatively high numbers of species $(n=27$ and $n=45$, respectively). 


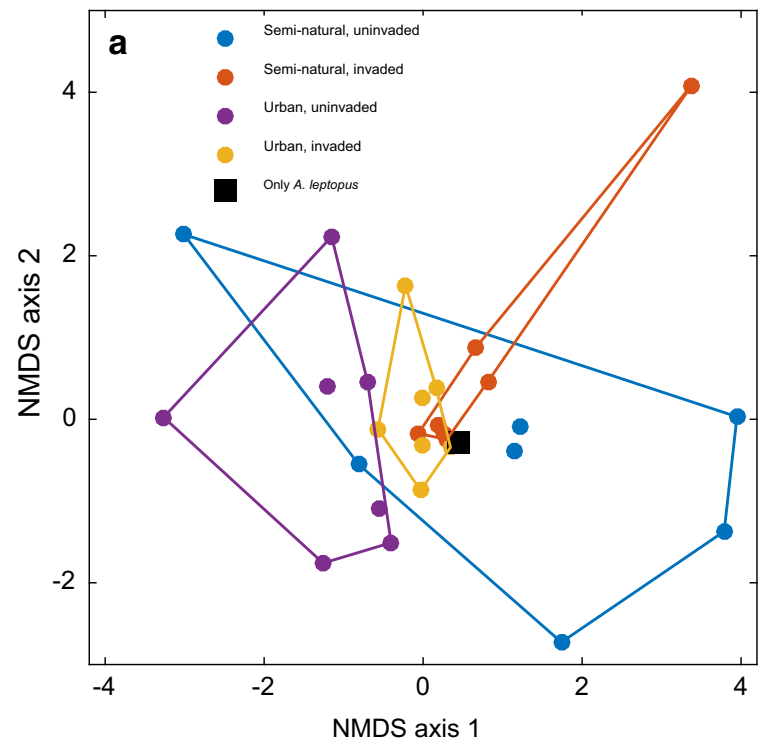

Fig. 4 Ordination of plant community composition in $10 \mathrm{~m}$ by $10 \mathrm{~m}$ plots (left) and $2 \mathrm{~m}$ by $2 \mathrm{~m}$ subplots (right), which were either uninvaded or invaded by A. leptopus, and within urban or

Assessing change in the structure of recipient plant communities

Species co-occurrence patterns suggested that uninvaded communities were characterized by species segregation, as species tended to co-occur less frequently than what would be expected from random co-occurrence of plant species (Standardized Effect Size (SES) $>2$; Fig. 5). In contrast, species cooccurrence patterns in invaded plots were within the range that would be expected based on random cooccurrence of plant species (abs(SES) $<2$; Fig. 5). Hence, these invaded plant communities exhibited random co-occurrence patterns, meaning that there were no patterns consistent with either species aggregation or segregation.

Native and non-native species responses to A. leptopus invasion

There were 37 native species and six non-native species (besides A. leptopus) that appeared in five or more of the full plots studied. Three species, belonging to the genera Cyperus, Desmanthus and Galactica, also appeared in more than five plots, but could not be determined at the species level, meaning that their status (i.e. native or non-native) could not be

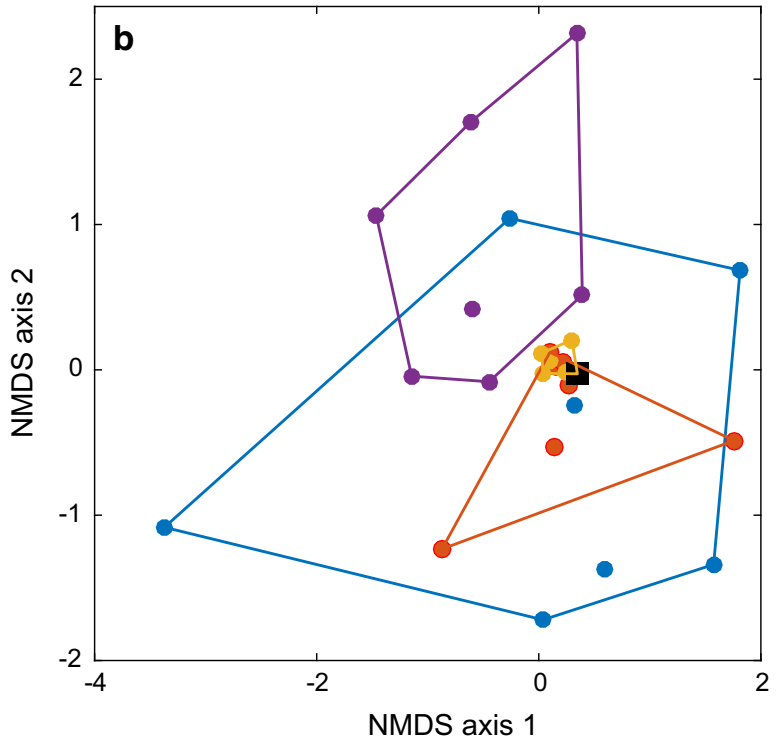

semi-natural land cover types. In both panels, a monoculture of A. leptopus is indicated with a black square

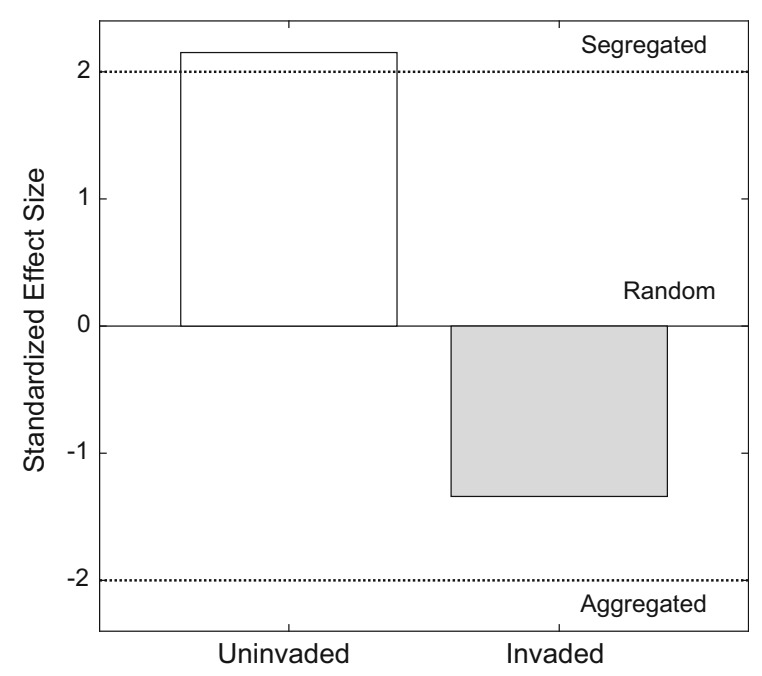

Fig. 5 Standardized effect sizes of plant community structure in plots invaded by A. leptopus and in uninvaded plots, as compared to randomly structured communities. The dotted lines indicate the +2 and -2 standard deviations levels separating random co-occurrence patterns from segregated and aggregated patterns, respectively.

determined either (Table 1). Considering the former two groups of plant species, there was no difference between native and non-native species regarding their tendency to co-occur with A. leptopus (two-sample t-test, $\quad \mathrm{SES}_{\text {native }}=2.11, \quad \mathrm{SES}_{\text {non-native }}=1.29$, 
Table 1 Frequency of occurrence of plant species in plots uninvaded and invaded by $A$

\begin{tabular}{|c|c|c|c|c|}
\hline Species name & $\begin{array}{l}\text { Status (native or non- } \\
\text { native) }\end{array}$ & $\begin{array}{l}\text { Occurrence in uninvaded plots } \\
(n=17)\end{array}$ & $\begin{array}{l}\text { Occurrence in invaded plots } \\
(n=17)\end{array}$ & SES \\
\hline Cuscuta americana & Native & 7 & 0 & 4.3025 \\
\hline Desmodium triflorum & Native & 9 & 2 & 4.1286 \\
\hline Vachellia macracantha & Native & 12 & 5 & 4.0901 \\
\hline Rauvolfia viridis & Native & 14 & 7 & 4.0567 \\
\hline Pisonia subcordata & Native & 6 & 0 & 3.8395 \\
\hline Stylosanthes hamata & Native & 9 & 3 & 3.4905 \\
\hline Senna bicapsularis & Native & 8 & 2 & 3.451 \\
\hline $\begin{array}{l}\text { Quadrella } \\
\text { cynophallophora }\end{array}$ & Native & 5 & 0 & 3.4423 \\
\hline Physalis pubescens & Native & 5 & 0 & 3.325 \\
\hline $\begin{array}{l}\text { Desmodium } c f \text {. } \\
\text { tortuosum }\end{array}$ & Native & 8 & 3 & 3.0645 \\
\hline Sida glomerata & Native & 10 & 5 & 2.884 \\
\hline Phyllanthus amarus & Native & 5 & 1 & 2.6219 \\
\hline Opuntia triacanthos & Native & 5 & 1 & 2.6154 \\
\hline Ruellia tuberosa & Native & 5 & 1 & 2.5916 \\
\hline Catharanthus rosea & Non-native & 6 & 2 & 2.5081 \\
\hline $\begin{array}{l}\text { Dactyloctenium } \\
\text { aegyptium }\end{array}$ & Non-native & 8 & 4 & 2.4049 \\
\hline Melochia tomentosa & Native & 4 & 1 & 2.2061 \\
\hline $\begin{array}{l}\text { Anthephora } \\
\text { hermaphroditica }\end{array}$ & Native & 4 & 1 & 2.1587 \\
\hline Vachellia tortuosa & Native & 4 & 1 & 2.1134 \\
\hline Citharexylum spinosum & Native & 4 & 1 & 2.0972 \\
\hline Pentalinon luteum & Native & 4 & 1 & 2.0797 \\
\hline Azadirachta indica & Non-native & 5 & 2 & 2.079 \\
\hline Solanum bahamense & Native & 11 & 8 & 2.0503 \\
\hline Justicia sessilis & Native & 5 & 2 & 2.0014 \\
\hline Randia aculeata & Native & 7 & 4 & 1.9807 \\
\hline Lantana involucrata & Native & 6 & 3 & 1.9774 \\
\hline Spermacoce remota & Native & 11 & 9 & 1.6201 \\
\hline Leucaena leucocephala & Non-native & 8 & 6 & 1.5646 \\
\hline Volkameria aculeata & Native & 4 & 2 & 1.5589 \\
\hline Heteropterys purpurea & Native & 5 & 3 & 1.5261 \\
\hline Corchorus aestuans & Native & 4 & 2 & 1.4791 \\
\hline $\begin{array}{l}\text { Stigmaphyllon } \\
\text { emarginatum }\end{array}$ & Native & 4 & 2 & 1.4675 \\
\hline Sida cordifolia & Native & 9 & 8 & 1.1158 \\
\hline Commelina erecta & Native & 5 & 4 & 1.0684 \\
\hline Galactica sp. & Undetermined & 4 & 3 & 1.0371 \\
\hline Waltheria indica & Native & 6 & 5 & 1.0014 \\
\hline $\begin{array}{l}\text { Heliotropium } \\
\text { angiospermum }\end{array}$ & Native & 4 & 3 & 0.9919 \\
\hline Melochia pyramidata & Native & 4 & 3 & 0.9673 \\
\hline Cyperus sp. & Undetermined & 9 & 11 & -0.016 \\
\hline
\end{tabular}


Table 1 continued

\begin{tabular}{|c|c|c|c|c|}
\hline Species name & $\begin{array}{l}\text { Status (native or non- } \\
\text { native) }\end{array}$ & $\begin{array}{l}\text { Occurrence in uninvaded plots } \\
(n=17)\end{array}$ & $\begin{array}{l}\text { Occurrence in invaded plots } \\
(n=17)\end{array}$ & SES \\
\hline Desmanthus sp. & Undetermined & 2 & 3 & -0.0478 \\
\hline Annona muricata & Native & 2 & 3 & -0.0599 \\
\hline Lippia alba & Native & 2 & 3 & -0.0948 \\
\hline $\begin{array}{l}\text { Centrosema } \\
\text { virginianum }\end{array}$ & Native & 6 & 8 & -0.1021 \\
\hline Abrus precatorius & Non-native & 2 & 4 & -0.4915 \\
\hline Bothriochloa pertusa & Non-native & 13 & 16 & -0.836 \\
\hline Jatropha gossypifolia & Native & 14 & 17 & -1.2713 \\
\hline
\end{tabular}

leptopus on St. Eustatius, northern Caribbean. From the co-occurrence patterns of each species with A. leptopus, pairwise Standardized Effects Scores (SES) are calculated. SES scores below -2 indicate that co-occurrence with A. leptopus is more likely than expected from random occurrence. SES scores above 2 indicate that co-occurrence is less likely than expected from random cooccurrence. The table lists the subset of 43 species (besides A. leptopus) that occurred at least five times in the surveyed plots. Bold values indicate species that showed significant segregation from A. leptopus

$\left.\mathrm{t}_{41}=1.38, \mathrm{p}=0.17\right)$. Of the species that occurred at least five times in the dataset, $52 \%$ had a significantly positive C-score, reflecting a reduced occurrence in $A$. leptopus-invaded plots. This group consisted of 21 native species and three non-native species (Table 1). In contrast, none of the species had a significantly negative $\mathrm{C}$-score, which would reflect an increased occurrence in invaded plots. The group of eight species that did have a negative (yet not significant) C-score consisted of four native species (Jatropha gossypiifolia, Centrosema virginianum, Lippia alba and Annona muricata, Table 1), two non-native species (Botrichloa pertusa and Abrus precatorius, Table 1), as well as the Cyperus and Desmanthus spp. mentioned above (Table 1).

\section{Discussion}

There is an urgent need to increase our understanding of the impacts of non-native plant invasions on the relatively high and unique biodiversity of (sub-)tropical islands, as these systems are particularly susceptible to plant invasions (Kueffer et al. 2010; Essl et al. 2019). In these systems, invasive vines form a particular risk given their potential to modify environmental conditions and exert strong effects on recipient plant communities (Gordon 1998; Harris et al. 2007; Bray et al. 2017; Gordon et al. 2017). Although A. leptopus is a prominent example of a vine that has successfully invaded (sub-)tropical islands around the globe, its impacts on recipient plant communities have not yet been systematically quantified. In this study, we systematically assessed the impact of A. leptopus on species richness, community homogenization, community disassembly and species-specific responses to invasion.

Corroborating our first hypothesis, there was a linear decline in species richness with increasing cover of A. leptopus, yielding levels of species richness that were $40 \%-50 \%$ lower than observed in uninvaded paired plots. This potential impact of A. leptopus on species richness is similar to the impacts observed for the most successful non-native wetland invaders in central Europe (Hejda et al. 2009), and is considerably higher than the average impact on species richness of primary producers in terrestrial habitats (16\%) as obtained from meta-analysis (Mollot et al. 2017). Indeed, many non-native plant species seem to have smaller impacts on recipient plant communities, as observations of non-native and native species richness also include weakly negative or even positive relationships (Seabloom et el. 2013; Martin-Forés et al. 2016, 2017), even at the relatively small plot scales considered in this study (Peng et al. 2019). Furthermore, at the smaller subplot scale, impacts were more negative and stronger in areas with urban land cover than in areas with semi-natural land cover. Although these latter findings corroborated with previous findings of invasive species impacts in semi-natural and 
urban landscapes (González-Moreno et al. 2017; Gutiérrez-Cánovas et al. 2020), it should be noted that in these previous studies the semi-natural and urban habitats comprised a disturbance gradient within the same type of (coastal) ecosystem. In our current study, two levels of disturbance were considered, with the difference corresponding to a change from forest communities in semi-natural landscapes to grasslands in urban landscapes. Hence, we could not disentangle the effects of differential biotic resistance of grassland-dominated and forest-dominated landscapes, and the degree of disturbance, for example. Future studies could also sample disturbance gradients within each type of land cover, in order to assess the interaction between A. leptopus invasion and disturbance in further detail (González-Moreno et al. 2017; Gutiérrez-Cánovas et al. 2020).

The results also corroborated our second hypothesis, suggesting that $A$. leptopus invasion homogenizes recipient plant communities. Observing biotic homogenization at the relatively small spatial scales examined suggests that the focal invasive species is a strong competitor that reduces community diversity and complexity (Lambdon et al. 2008). We did not find evidence for A. leptopus driving a turnover in plant community composition, as the composition of invaded plots occupied a subset of the community space spanned by uninvaded plots. Community turnover could be the result of an 'invasional meltdown' process, where the successful invasion of one species triggers subsequent invasions (Simberloff and Von Holle 1999; Simberloff 2006). The lack of turnover is again consistent with A. leptopus being a strong competitor, which may also limit the establishment of other non-native plant species and thereby reduce the potential for invasional meltdown (Rauschert and Shea 2017).

Consistent with our third hypothesis, we found evidence for species segregation in uninvaded plots, pointing to the competitive interactions expected in benign environments (Maestre et al. 2009; Santoro et al. 2012; de Miguel et al. 2016). In contrast, cooccurrence patterns in invaded plots were not significantly different from expectations based on random co-occurrence. This change toward less segregation may be explained by species' persistence being limited to the invasion stages where A. leptopus is not yet fully dominant. The resulting co-occurrence patterns in invaded plots suggest that A. leptopus invasion is associated with the disassembly of recipient plant communities. Our results suggest that the order of species loss due to invasion may be driven by stochastic processes, as most species exhibited reduced occurrence in plots invaded by A. leptopus, while none exhibited significant increases in occurrence. This latter observation is inconsistent with our fourth hypothesis, which stated that other non-native species may be better able to coexist with A. leptopus (Stotz et al. 2020). It should be noted, however, that the relatively small number of non-native species included in our test of this hypothesis offered limited power, and hence hampered generalization of our findings into broader conclusions about native and non-native species responses to A. leptopus invasion. This type of community disassembly can emerge as a result of altered interactions between species (Sanders et al. 2003), or as a result of these interactions becoming a less important driver of community dynamics when superseded by the impacts of the successful invasive species (e.g. Chen et al. 2020). Together with the other lines of results presented above, our findings point to the latter mechanism in the case of A. leptopus' invasion on St. Eustatius. More specifically, our results suggest that A. leptopus invasion leads to local exclusion of plant species. Furthermore, our results are consistent with A. leptopus being a superior competitor, exerting similarly negative effects on all species within recipient plant communities, and potentially leaving few opportunities for other (non-native) species to establish. While we did not study the specific mechanisms driving the competition between A. leptopus and other plant species, previous research suggests that both belowground competition (for water and soil nutrients, Dillenburg et al. 1993; Meunier et al. 2021) and aboveground competition (for light, Paul and Yavitt 2011; Meunier et al. 2021) may be important to consider when studying these competitive interactions between vines and recipient plant communities.

The fieldwork for this study was carried out at one period in time, providing a snapshot of recipient plant community diversity and structure. Although the paired-plot design aims to maximize the comparability of uninvaded and invaded plots (e.g. Vilà et al. 2006; Castro-Díez et al. 2016), the retrospective nature of the analysis makes it impossible to fully attribute differences within plot pairs to the invasion of the focal species of interest (e.g. Sanders et al. 2003). Although 
inferred levels of species richness in invaded plots with relatively low A. leptopus cover were similar to those observed in uninvaded plots (Figs. 2, 3), previous studies have also suggested that A. leptopus may need some form of disturbance to gain a foothold in recipient plant communities (Ernst and Ketner 2007). However, once established, A. leptopus may drive additional plant community processes that exacerbate the initial disturbance, in line with the idea of invasive species acting as "back-seat drivers" of ecosystem change (Bauer 2012). The uninvaded plots described in this study contribute to other recent observations describing pre-invasion conditions on St. Eustatius (e.g. Van Andel et al. 2016; Madden et al. 2019), which may provide valuable reference data in the future that allow for a more direct assessment of the consequences of invasion using a longitudinal design.

In this study, we took a taxonomic perspective on quantifying plant community diversity and structure. Recent research has proposed various ways to use plant functional traits to link taxonomic diversity to ecosystem structure and functioning (Mayfield et al. 2005; Villéger et al. 2008; Laliberté and Legendre 2010; Van Kleunen et al. 2010; Drenovsky et al. 2012; Laliberté and Tylianakis 2012; Molinari and D'Antonio 2014; Castro-Díez et al. 2016). Plant functional trait diversity is not necessarily related to taxonomic diversity, as plant communities may vary in the degree of functional redundancy (Mayfield et al. 2005; Funk et al. 2017; Gutiérrez-Cánovas et al. 2020). Analyses of changes in plant functional diversity could highlight which specific ecosystem functions may be affected by A. leptopus invasion (cf. Molinari and D'Antonio 2014). Such consequences of plant invasions on ecosystem functioning and the provisioning of ecosystem services are an important concern (Tordoni et al. 2019; Milanović et al. 2020). Although recent research has attempted to assess the functional implications of A. leptopus invasion in the Caribbean using a traitbased approach, current gaps in species trait data availability need to be filled in order to answer this question confidently (Sweeney 2018). Given the unique evolutionary history of the Caribbean, a phylogenetic approach would provide another valuable and complementary perspective (Veron et al. 2017). More specifically, such a perspective could provide a link between reductions in recipient plant community richness, and the extent to which this reduction leads to a loss in both phylogenetic diversity and evolutionary distinctiveness within invaded areas (Jucker et al. 2013; Veron et al. 2017). The latter component of biodiversity is particularly relevant for setting conservation priorities (Lehtomäki et al. 2019).

Projected environmental changes in the Caribbean region, such as the increased frequency of strong hurricanes (Knutson et al. 2015; Eppinga and Pucko 2018), may fundamentally alter disturbance regimes of Caribbean ecosystems. Alterations of disturbance regimes may affect the frequency of non-native species introductions, and alter competitive interactions between native and non-native species already present (White et al. 2006). In general, invasive species are often capable of exploiting ecosystem disturbances as a means to gain competitive advantage over native species (Moles et al. 2008; Van Kleunen et al. 2010; Jauni et al. 2015). Similar behavior has been attributed to A. leptopus (Ernst and Ketner 2007; Vandebroek et al. 2018; Heger and Van Andel 2019; Eppinga et al. 2021; Haber et al. 2021). Here we showed how A. leptopus invasion is associated with substantial changes in recipient plant community diversity and structure. Combining multiple lines of observation, we conclude that the impacts of $A$. leptopus are consistent with those of a strong competitor that exerts strong negative effects on most species of the recipient plant community. Locally, these negative effects may induce a stochastic exclusion process that leads to more homogenized subsets of pre-invasion communities, which is reflected in random co-occurrence patterns. These results highlight the need to develop monitoring programs to study the relationship between initial disturbances, invasion by A. leptopus and subsequent impacts of the invasion on ecosystem functioning. Such monitoring programs may aid in articulating the need to develop management strategies that prevent or limit the expansion and impacts of invasive species and maintain the unique biodiversity within Caribbean ecosystems (Maunder et al. 2008; Banda et al. 2016; Debrot et al. 2018; Rojas-Sandoval and Ackerman 2020).

Acknowledgements This work was funded by the Dutch Organization for Scientific Research (NWO, grant number 858.14.052). In addition, M.J.S. was funded by the University of Zurich's University Research Priority Program in Global Change and Biodiversity. We are grateful for the logistical support, lab space, and local expertise provided by the helpful staff at the Caribbean Netherlands Science Institute and the St. Eustatius Center for Archaeological Research. We very much 
appreciate the help given by T. van Andel and A.P.M. van der Zon for species determinations. Gratitude also goes to Rotem Zilber, our dedicated and careful field assistant.

Funding Open Access funding provided by Universität Zürich. This work was funded by the Dutch Organization for Scientific Research (NWO, grant number 858.14.052). In addition, M.J.S. was funded by the University of Zurich's University Research Priority Program in Global Change and Biodiversity.

Availability of data and material Source data underlying this manuscript can be accessed from the Yoda Data Repository of Utrecht University at https://doi.org/10.24416/UU01S9NW62

Code availability Matlab code written to perform the described analyses are available from the corresponding author upon reasonable request.

\section{Declarations}

Conflicts of interest The authors have no relevant financial or non-financial interests to disclose.

Open Access This article is licensed under a Creative Commons Attribution 4.0 International License, which permits use, sharing, adaptation, distribution and reproduction in any medium or format, as long as you give appropriate credit to the original author(s) and the source, provide a link to the Creative Commons licence, and indicate if changes were made. The images or other third party material in this article are included in the article's Creative Commons licence, unless indicated otherwise in a credit line to the material. If material is not included in the article's Creative Commons licence and your intended use is not permitted by statutory regulation or exceeds the permitted use, you will need to obtain permission directly from the copyright holder. To view a copy of this licence, visit http://creativecommons.org/licenses/by/4.0/.

\section{References}

Axelrod FS (2017) A systematic vademecum to the vascular plants of Sint Eustatius. BRIT Press, Fort Worth, Texas, USA

Banda K et al (2016) Plant diversity patterns in neotropical dry forests and their conservation implications. Science 353:1383-1387

Barfknecht DF, Gibson DJ, Neubig KM (2020) Plant community and phylogenetic shifts in acid seep springs over 49 years following Microstegium vimineum invasion. Plant Ecol 221:167-175

Bauer JT (2012) Invasive species: "back-seat" drivers of ecosystem change? Biol Invasions 14:1295-1304

Bellard C, Cassey J, Blackburn TM (2016) Alien species as a driver of recent extinctions. Biol Lett 12:20150623
Blois JL, Zarnetske PL, Fitzpatrick MC et al (2013) Climate change and the past, present, and future of biotic interactions. Science 341:499-504

Boldingh I (1909) The Flora of the Dutch West Indian Islands St. Eustatius, Saba and St. Martin. E.J. Brill, Leiden, The Netherlands.

Bradley BA, Laginhas BB, Whitlock R, Allen JM, Bates AE, Bernatchez G, Diez JM, Early R, Lenoir J, Vilà M, Sorte CJB (2019) Disentangling the abundance-impact relationship for invasive species. Proc Nat Acad Sci USA 116:9919-9924

Bray SR, Hoyt AM, Yang Z, Arthur MA (2017) Non-native liana, Euonymus fortunei, associated with increased soil nutrients, unique bacterial communities, and faster decomposition rates. Plant Ecol 218:329-343

Brown JH, Sax DF (2004) An essay on some topics concerning invasive species. Austral Ecol 29:530-536

Burke JM, DiTomasso A (2011) Corallita (Antigonon leptopus): intentional introduction of a plant with documented invasive capability. Inv Plant Sci Manag 4:265-273

Casado MA, Acosta-Gallo B, Sánchez-Jardón L, Martín-Forés I, Castro I, Ovalle C, del Pozo A, de Miguel JM (2015) Interactive effects of source and recipient habitats on plant invasions: distribution of exotic species in Chile. Divers Distrib 21:609-619

Cassini MH (2020) A review of the critics of invasion biology. Biol Rev 95:1467-1478

Castro-Díez P, Pauchard A, Traveset A, Vilà M (2016) Linking the impacts of plant invasion on community functional structure and ecosystem properties. J Veg Sci 27:1233-1242

Chen J, Shiyomi M (2019) A power law for analyzing spatial patterns of vegetation abundance in terms of cover, biomass, density and occurrence: derivation of a common rule. J Plant Res 132:481-497

Chen L, Zhou J, Zeng T, Miao Y-F, Mei L, Yao G-B, Fang K, Dong X-F, Sha T, Yang M-Z, Li T, Zhao Z-W, Zhang H-B (2020) Quantifying the sharing of foliar fungal pathogens by the invasive plant Ageratina adenophora and its neighbours. New Phytol 227:1493-1504

Chiarucci A, Wilson JB, Anderson BJ, De Dominicis V (1999) Cover versus biomass as an estimate of species abundance: does it make a difference to the conclusions? J Veg Sci 10:35-42

Clarke KR (1993) Non-parametric multivariate analyses of changes in community structure. Aust J Ecol 18:117-143

Crooks JA (2002) Characterizing ecosystem-level consequences of biological invasions: the role of ecosystem engineers. Oikos 97:153-166

Cuddington K, Hastings A (2004) Invasive engineers. Ecol Model 335-247.

Dar PA, Reshi ZA (2015) Do alien plant invasions cause biotic homogenization of terrestrial ecosystems in the Kashmir Valley, India? Trop Ecol 56:111-123

Debrot AO, Henkens RJHG, Verweij PJFM (2018) Staat van de natuur van Caribisch Nederland 2017 (In Dutch). Wageningen Marine Research, Wageningen, The Netherlands.

Dostál P (2011) Plant competitive interactions and invasiveness: searching for the effects of phylogenetic relatedness and origin on competition intensity. Am Nat 177:655-667 
de Freitas JA, Rojer AC, Nijhof BSJ, Debrot AO (2012) A landscape ecological vegetation map of Sint Eustatius (Lesser Antilles). Royal Netherlands Academy of Sciences, Amsterdam, The Netherlands.

de la Riva EG, Godoy O, Castro-Díez P, Gutiérrez-Cánovas C, Vilà M (2019) Functional and phylogenetic consequences of plant invasion for coastal native communities. J Veg Sci 30:510-520

de Miguel JM, Martin-Forés I, Acosta-Gallo B, del Pozo A, Ovalle C, Sánchez-Jardón L, Castro I, Casado MA (2016) Non-random co-occurrence of native and exotic plant species in Mediterranean grasslands. Acta Oecol 77:18-26

Diekmann M, Effertz H, Baranowski M, Dupré C (2016) Weak effects on plant diversity of two invasive Impatiens species. Plant Ecol 12:1503-1514

Dillenburg LR, Whigham DF, Teramura AH, Forseth IN (1993) Effects of vine competition on availability of light, water, and nitrogen to a tree host (Liquidambar styraciflua). Am J Bot 80: 244-252

Drenovsky RE, Grewell BJ, D’ Antonio CM, Funk JL, James JJ, Molinari N, Parker IM, Richards CL (2012) A functional trait perspective on plant invasions. Ann Bot 110:141-153

Eppinga MB, Baudena M, Haber EA, Rietkerk M, Wassen MJ, Santos MJ (2021) Spatially explicit removal strategies increase the efficiency of invasive plant species control. Ecol Appl 31:e02257

Eppinga MB, Pucko CA (2018) The impact of hurricanes Irma and Maria on the forest ecosystems of Saba and St. Eustatius, northern Caribbean. Biotropica 50:723-728

Ernst JJ, Ketner P (2007) Study on the ecology and possible control methods of the invasive plant species Antigonon leptopus (Corallita or Mexican Creeper). ABC Research, Wageningen, The Netherlands.

Essl F, Dawson W, Kreft H, Pergl J, Pyšek P, Van Kleunen M, Weigelt P, Mang T, Dullinger S, Lenzner B, Moser D, Maurel N, Seebens H, Stein A, Weber E, Chatelain C, Inderjit GP, Kartesz J, Morozova O, Nishino M, Nowak PM, Pagad S, Shu W-S, Winter M (2019) Drivers of the relative richness of naturalized and invasive plant species on Earth. AoB Plants 11:plz051

Funk JL, Larson JE, Ames GM, Butterfield BJ, Cavender-Bares J, Firn J, Laughlin DC, Sutton-Grier AE, Williams L, Wright J (2017) Revisiting the Holy Grail: using plant functional traits to understand ecological processes. Biol Rev 92:1156-1173

Gaertner M, Den Breeyen A, Hui C, Richardson DM (2009) Impacts of alien invasions on species richness in Mediterranean-type ecosystems: a meta-analysis. Progr Phys Geogr 33:319-338

Galán Díaz J, de la Riva EG, Parker IM, Leiva MJ, BernardoMadrid R, Vilà M (2020) Plant community assembly in invaded recipient Californian grasslands and putative donor grasslands in Spain. Diversity 12:193

Gallego-Fernández JB, Martínez ML, García-Franco JG, Zunzunegui M (2019) The impact on plant communities of an invasive alien herb, Oenothera drummondii, varies along the beach-coastal dune gradient. Flora 260:151466

González-Moreno P, Pino J, Cózar A, García-de-Lomas J, Vilà M (2017) The effects of landscape history and time-lags on plant invasion in Mediterranean coastal habitats. Biol Inv 19:549-561
Gordon DR (1998) Effects of invasive, non-indigenous plant species on ecosystem processes: lessons from Florida. Ecol Appl 8:975-989

Gordon DR, Lieurance D, Flory SL (2017) Predicted versus actual invasiveness of climbing vines in Florida. Biol Inv 19:2375-2384

Gotelli NJ (2000) Null model analysis of species co-occurrence patterns. Ecology 81:2606-2621

Gotelli NJ, Entsminger GL (2001) Swap and fill algorithms in null model analysis: rethinking the knight's tour. Oecologia 129:281-291

Gotelli NJ, Rhode K (2002) Co-occurrence of ectoparasites of marine fishes: a null model analysis. Ecol Lett 5:86-94

Gotelli NJ, Ulrich W (2010) The empirical Bayes approach as a tool to identify non-random species associations. Oecologia 162:463-477

Gutiérrez-Cánovas C, Sánchez-Fernández D, González-Moreno P, Mateos-Naranjo E, Castro-Díez P, Vilà M (2020) Combined effects of land-use intensification and plant invasion on native communities. Oecologia 192:823-836

Haber EA, Santos MJ, Leitão PJ, Schwieder M, Ketner P, Ernst J, Rietkerk M, Wassen MJ, Eppinga MB (2021) Using high-resolution mapping to identify habitat characteristics of the invasive vine Antigonon leptopus. Biotropica 53:941-953

Harris CJ, Murray BR, Hose GC, Hamilton MA (2007) Introduction history and invasion success in exotic vines introduced to Australia. Divers Distrib 13:467-475

Heard MJ, Sax DF, Bruno JF (2012) Dominance of non-native species increases over time in a historically invaded strandline community. Divers Distrib 18:1232-1242

Hedman CW, Grace SL, King SE (2000) Vegetation composition and structure of southern coastal plain pine forests: an ecological comparison. Forest Ecol Manag 134:233-247

Heger WT, Van Andel T (2019) A social-ecological perspective on ecosystem vulnerability for the invasive creeper coralita (Antigonon leptopus) in the Caribbean: a review. Glob Ecol Conserv 18:e00605

Hejda M, Pyšek P, Jarošík V (2009) Impact of invasive plants on the species richness, diversity and composition of invaded communities. J Ecol 97:393-403

Horvitz CC, Pascarella JB, McMann S, Freedman A, Hofstetter RH (1998) Functional roles of invasive non-indigenous plants in hurricane-affected subtropical hardwood forests. Ecol Appl 8:947-974

Huebner CD, Nowak DJ, Pouyat RV, Bodine AR (2012) Nonnative invasive plants: maintaining biotic and socioeconomic integrity along the urban-rural-natural area gradient. In: Laband DN, Lockaby BG, Zipperer WC (eds) Urbanrural interfaces: linking people and nature. American Society of Agronomy, Madison, pp 71-98

Jauni M, Gripenberg S, Ramula S (2015) Non-native species benefit from disturbance: a meta-analysis. Oikos 124:122-129

Jucker T, Carboni M, Acosta AT (2013) Going beyond taxonomic diversity: deconstructing biodiversity patterns reveals the true cost of iceplant invasion. Divers Distrib 19:1566-1577

Kaproth MA, Eppinga MB, Molofsky J (2013) Leaf litter variation influences invasion dynamics in the invasive wetland grass Phalaris arundinacea. Biol Inv 15:1819-1832 
Khanna S, Santos MJ, Hestir EL, Ustin SL (2012) Plant community dynamics relative to the changing distribution of a highly invasive species, Eichhornia crassipes: A remote sensing perspective. Biol Inv 14:717-733

Knutson TR, Sirutis JJ, Zhao M, Tuleya RE, Bender M, Vecchi GA, Villarini G, Chavas D (2015) Global projections of intense tropical cyclone activity for the late twenty-first century from dynamical downscaling of CMIP5/RCP4.5 scenarios. J Climate 28:7203-7224

Kortz AR, Magurran AE (2019) Increases in local richness ( $\alpha$ diversity) following invasion are offset by biotic homogenization in a biodiversity hotspot. Biol Lett 15:20190133

Kueffer C, Daehler CC, Torres-Santana CW, Lavergne C, Meyer J-Y, Otto R, Silva L (2010) A global comparison of plant invasions in oceanic islands. Persp Plant Ecol Evol Syst 12:145-161

Lai HR, Mayfield MM, Gay-des-combes JM, Spiegelberger T, Dwyer JM (2015) Distinct invasion strategies operating within a natural annual plant system. Ecol Lett 18:336-346

Laliberté E, Legendre P (2010) A distance-based framework for measuring functional diversity from multiple traits. Ecology 91:299-305

Laliberté E, Tylianakis JM (2012) Cascading effects of longterm land-use changes on plant traits and ecosystem functioning. Ecology 93:145-155

Lambdon PW, Lloret F, Hulme PE (2008) Do non-native species invasions lead to biotic homogenization at small scales? The similarity and functional diversity of habitats compared for alien and native components of Mediterranean floras. Divers Distrib 14:774-785

Lehsten P, Harmand P (2006) Null models for species co-occurrence patterns: assessing bias and minimum iteration number for the sequential swap. Ecography 29:786-792

Lehtomäki J, Kusumoto B, Shiono T, Tanaka T, Kubota Y, Moilanen A (2019) Spatial conservation prioritization for the East Asian islands: a balanced representation of multitaxon biogeography in a protected area network. Divers Distrib 25:414-429

Li D, Waller DM (2016) Long-term shifts in the patterns and underlying processes of plant associations in Wisconsin forests. Global Ecol Biogeogr 25:516-526

Lowry E, Rollinson EJ, Laybourn AJ, Scott TE, Aiello-Lammens ME, Gray SM, Mickley J, Gurevitch J (2013) Biological invasions: a field synopsis, systematic review, and database of the literature. Ecol Evol 3:182-196

Macdonald R, Hawkesworth CJ, Heath E (2000) The Lesser Antilles volcanic chain: study in arc magmatism. Earth Sci Rev 49:1-76

MacDougall AS, Turkington R (2005) Are invasive species the drivers or passengers of change in degraded ecosystems? Ecology 86:42-55

Madden H, Van Andel T, Miller J, Stech M, Verdel K, Eggermont E (2019) Vegetation associations and relative abundance of rodents on St Eustatius Caribbean Netherlands. Glob Ecol Conserv 20:e00743

Maestre FT, Callaway RM, Valladares F, Lortie CJ (2009) Refining the stress-gradient hypothesis for competition and facilitation in plant communities. J Ecol 97:199-205

Mangla S, Sheley RL, James JJ, Radosevich SR (2011) Intra and interspecific compeition among invasive and native species during early stages of plant growth. Plant Ecol 212:531-542

Martín-Forés I, Sánchez-Jardón L, Acosta-Gallo B, Del Pozo A, Castro I, de Miguel JM, Ovalle C, Casado MA (2015) From Spain to Chile: environmental filters and success of herbaceous species in Mediterranean-climate regions. Biol Inv 17:1425-1438

Martín-Forés I, Castro I, Acosta-Gallo B, Del Pozo A, SánchezJardón L, de Miguel JM, Ovalle C, Casado MA (2016) Alien plant species coexist over time with native ones in Chilean Mediterranean grasslands. J Plant Ecol 9:682-691

Martín-Forés I, Guerin GR, Lowe AJ (2017) Weed abundance is positively correlated with native plant diversity in grasslands of southern Australia. PLoS ONE 12:e0178681

Maunder M, Leiva A, Santiago-Valentín E, Stevenson DW, Acevedo-Rodríguez P, Meerow AW, Mejía M, Clubbe C, Francisco-Ortega J (2008) Plant conservation in the Caribbean island biodiversity hotspot. Bot Rev 74:197-207

Mayfield MM, Boni ME, Daily GC, Ackerly D (2005) Species and functional diversity of native and human-dominated plant communities. Ecology 86:2365-2372

McCune B, Grace JB (2002) Analysis of Ecological Communities. MjM Software Design, Glenden Beach, Oregon, USA.

McKinney ML, Lockwood JL (1999) Biotic homogenization: a few winners replacing many losers in the next mass extinction. Trends Ecol Evol 14:450-453

Meunier F, Verbeeck H, Cowdery B, Schnitzer SA, SmithMartin CM, Powers JS, Xu X, Slot M, De Deurwaerder HP, Detto M, Bonal D (2021) Unraveling the relative role of light and water competition between lianas and trees in tropical forests: a vegetation model analysis. J Ecol 109: 519-540

Michaels TK, Eppinga MB, Bever JD (2020) A nucleation framework for transition between alternate states: shortcircuiting barriers to ecosystem recovery. Ecology 101:e03099

Milanović M, Knapp S, Pyšek P, Kühn I (2020) Ecosyst Serv. vol 42. p 101072

Mitchell SA, Kitson-Walters KA, Mitchell AA (2019) Valuing Caribbean biodiversity knowledge. In: Hufnagel L (ed) Changing ecosystems and their services. IntechOpen, London, pp 15-48

Moles AT, Gruber MAM, Bonser SP (2008) A new framework for predicting invasive plant species. J Ecol 96:13-17

Molinari NA, D'Antonio CM (2014) Structural, compositional and trait differences between native- and non-nativedominated grassland patches. Funct Ecol 28:745-754

Mollot G, Pantel JH, Romanuk TN (2017) The effects of invasive species on the decline in species richness: a global meta-analysis. Adv Ecol Res 56:61-83

Myers N, Mittermeier RA, Mittermeier CG, Da Fonseca GAB, Kent J (2000) Biodiversity hotspots for conservation priorities. Nature 403:853-858

Naturalis Biodversity Center (2017) Dutch Caribbean Species Register, www.dutchcaribbeanspecies.org. Last accessed: March 09, 2020.

Olden JD, Poff NLR, Douglas MR, Douglas ME, Fausch KD (2004) Ecological and evolutionary consequences of biotic homogenization. Trends Ecol Evol 19:18-24 
Olson L (2006) The economics of terrestrial invasive species: a review of the literature. Agric Resour Econ Rev 35:178-194

Paul GS, Yavitt JB (2011) Tropical vine growth and the effects on forest succession: a review of the ecology and management of tropical climbing plants. Bot Rev 77:11-30

Pejchar L, Mooney HA (2009) Invasive species, ecosystem services and human well-being. Trends Ecol Evol 24:497-504

Peng S, Kinlock NL, Gurevitch J, Peng S (2019) Correlation of native and exotic species richness: a global meta-analysis finds no invasion paradox across scales. Ecology 100:1-10

Pucko CA, Beckage B, Perkins TJ, Keeton WJ (2011) Species shifts in response to climate change: individual or shared responses? J Torrey Bot Soc 138:156-176

Pyšek P, Richardson DM, Pergl J, Jarošik V, Sixtová Z, Weber V (2008) Geographical and taxonomic biases in invasion ecology. Trends Ecol Evol 23:237-244

Pyšek P, Blackburn TM, García-Berthou E, Perglová I, Rabitsch W (2017) Displacement and local extinction of native and endemic species. In: Vilà M, Hulme PE (eds) Impact of biological invasions on ecosystem services. Springer International Publishing, Cham, Switzerland, pp 157-175

Rauschert ESJ, Shea K (2017) Competition between similar invasive species: modeling invasional interference across a landscape. Pop Ecol 59:79-88

Reed HE, Seastedt TR, Blair JM (2005) Ecological consequences of $\mathrm{C} 4$ grass invasion of a $\mathrm{C} 4$ grassland: a dilemma for management. Ecol Appl 15:1560-1569

Rojas-Sandoval J, Ackerman JD (2020) Island biogeography of native and alien plant species: contrasting drivers of diversity across the Lesser Antilles. Divers Distrib 26:1539-1550

Rojer AC (1997) Biological Inventory of Sint Eustatius. Carmabi Foundation, Curaçao, Netherlands Antilles.

Roobol MJ, Smith AL (2004) Volcanology of Saba and St. Eustatius, Northern Lesser Antilles. Royal Netherlands Academy of Sciences, Amsterdam, The Netherlands.

Sanders NJ, Gotelli NJ, Heller NE, Gordon DM (2003) Community disassembly by an invasive species. Proc Nat Acad Sci USA 100:2474-2477

Santoro R, Jucker T, Carboni M, Acosta AT (2012) Patterns of plant community assembly in invaded and non-invaded communities along a natural environmental gradient. J Veg Sci 23:483-494

Santos MJ, Anderson LW, Ustin SL (2011) Effects of invasive species on plant communities: an example using submersed aquatic plants at the regional scale. Biol Inv 13:443-457

Sax DF, Gaines SD (2008) Species invasions and extinction: The future of native biodiversity on islands. Proc Nat Acad Sci USA 105:11490-11497

Schnitzer SA (2005) A mechanistic explanation for global patterns of liana abundance and distribution. Am Nat 166:262-276

Schnitzer SA, Bongers F (2011) Increasing liana abundance and biomass in tropical forests: emerging patterns and putative mechanisms. Ecol Lett 14:397-406

Seabloom EW et al (2013) Predicting invasion in grassland ecosystems: is exotic dominance the real embarassment of richness? Glob Change Biol 19:3677-3687
Shackleton RT, Shackleton CM, Kull CA (2019) The role of invasive alien species in shaping local livelihoods and human well-being: a review. J Environ Manage 229:145-157

Simberloff D (2006) Invasional meltdown 6 years later: important phenomenon, unfortunate metaphor, or both? Ecol Lett 9:912-919

Simberloff D, Von Holle B (1999) Positive interactions of nonindigenous species: invasional meltdown? Biol Inv $1: 21-32$

Sloan S, Jenkins CN, Joppa LN, Gaveau DLA, Laurance WF (2014) Remaining natural vegetation in the global biodiversity hotspots. Biol Conserv 177:12-24

Stoffers AL (1956) The vegetation of the Netherlands Antilles. Uitgaven Natuurwetenschappenlijke Studiekring voor Suriname en de Nederlandse Antillen 15.

Stone L, Roberts A (1990) The checkerboard score and species distributions. Oecologia 85:74-79

Stotz GC, Cahill JF Jr, Bennett JA, Carlyle CN, Bork EW, Askarizadeh D, Bartha S, Beierkuhnlein C, Boldgiv B, Brown L, Cabido M, Campetella G, Chelli S, Cohen O, Díaz S, Enrico L, Ensing D, Erdenetsetseg B, Fidelis A, Garris HW, Henry HAL, Jentsch A, Jouri MH, Koorem K, Manning P, Mitchell R, Moora M, Overbeck GE, Pither J, Reinhart KO, Sternberg M, Tungalag R, Undrakhbold S, van Rooyen M, Wellstein C, Zobel M, Fraser LH (2020) Not a melting pot: plant species aggregate in their nonnative range. Global Ecol Biogeogr 29:482-490

Surendra B, Muhammed AA, Raju SAJ (2013) Invasive alien plant species assessment in urban ecosystem: a case study from Andhra University, Visakhapatnam, India. Int Res J Env Sci 2:79-86

Sweeney L (2018) Assessing the impact of A. leptopus on Saba and St. Eustatius. MSc thesis. Utrecht University, Utrecht, The Netherlands.

Thiele J, Kollmann J, Markussen B, Otte A (2010) Impact assessment revisited: improving the theoretical basis for management of invasive alien species. Biol Inv 12:2025-2035

Tordoni E, Petruzzellis F, Nardini A, Savi T, Bacaro G (2019) Make it simpler: alien species decrease functional diversity of coastal plant communities. J Veg Sci 30:498-509

Traveset A, Richardson DM (2006) Biological invasions as disruptors of plant reproductive mutualisms. Trends Ecol Evol 21:208-216

Ulrich W (2004) Species co-occurrences and neutral models: reassessing. J M Diamond's Assembly Rules Oikos 107:603-609

Ulrich W, Gotelli NJ (2010) Null model analysis of species associations using abundance data. Ecology 91:3384-3397

Ulrich W, Gotelli NJ (2013) Pattern detection in null model analysis. Oikos 122:2-18

Ulrich W, Jabot F, Gotelli NJ (2017) Competitive interactions change the pattern of species co-occurrence under neutral dispersal. Oikos 126:91-100

Van Andel T, Van der Hoorn B, Stech M, Bantjes Arostegui S, Miller J (2016) A quantitative assessment of the vegetation types on the island of St. Eustatius. Dutch Caribbean Global Ecol Conserv 7:59-69

Vandebroek I, Picking D, Lewis PA, Oberli A, Aiken S, Mitchell S, Boom B (2018) A review of Coralilla 
(Antigonon leptopus): an invasive and popular urban bush medicine in Jamaica. Econ Bot 72:229-245

Van der Burg WJ, Freitas JA de, Debrot AO, Lotz LAP (2012) Naturalised and invasive alien plant species in the Caribbean Netherlands: status, distribution, threats, priorities and recommendations. Alterra, Wageningen, The Netherlands.

Van Kleunen M, Weber E, Fischer M (2010) A meta-analysis of trait differences between invasive and non-invasive plant species. Ecol Lett 13:235-245

Veech JA (2014) The pairwise approach to analysing species cooccurrence. J Biogeogr 41:1029-1035

Veron S, Davies TJ, Cadotte MW, Ciergeau P, Pavoine S (2017) Predicting loss of evolutionary history: where are we? Biol Rev 92:271-291

Verwijmeren M, Rietkerk M, Bautista S, Mayor AG, Wassen MJ, Smit C (2014) Drought and grazing combined: contrasting shifts in plant interactions at species pair and community level. J Arid Env 111:53-60

Vilà M, Bartomeus I, Dietzsch AC, Petanidou T, SteffanDewenter I, Stout JC, Tscheulin T (2009) Invasive plant integration into native plant-pollinator networks across Europe. Proc Roy Soc B 276:3887-3893

Vilà M, Espinar JL, Hejda M, Hulme PE, Jarošík V, Maron JL, Pergl J, Schaffner U, Sun Y, Pyšek P (2011) Ecological impacts of invasive alien plants: a meta-analysis of their effects on species, communities and ecosystems. Ecol Lett 14:702-708

Vilà M, Tessier M, Suehs CM, Brundu G, Carta L, Galanidis A, Lambdon P, Manca M, Médail F, Moragues E, Traveset A,
Troumbis AY, Hulme PE (2006) Local and regional assessments of the impacts of plant invaders on vegetation structure and soil properties of Mediterranean islands. J Biogeogr 33:853-861

Villéger S, Mason NW, Mouillot D (2008) New multidimensional functional diversity indices for a multifaceted framework in functional ecology. Ecology 89:2290-2301

Waller DM, Mudrak EL, Amatangelo KL, Klionsky SM, Rogers DA (2016) Do associations between native and invasive plants provide signals of invasive impacts? Biol Invasions 18:3465-3480

Ward EB, Pregitzer CC, Kuebbing SE, Bradford MA (2020) Invasive lianas are drivers of and passengers to altered soil nutrient availability in urban forests. Biol Inv 22:935-955

White EM, Wilson JC, Clarke AR (2006) Biotic indirect effects: a neglected concept in invasion biology. Divers Distrib 12:443-455

Zavaleta E, Pasari J, Moore J, Hernandez D, Suttle KB, Wilmers CC (2009) Ecosystem responses to community disassembly. Ann NY Acad Sci 1162:311-333

Zhang G, Li J, Zhang Y, Zhou S (2017) Cutting rapid propagation technology for Antigonon leptopus in tropical areas. Agric Biotechnol 6:20-22

Publisher's Note Springer Nature remains neutral with regard to jurisdictional claims in published maps and institutional affiliations. 